\title{
Analysis Acceptance of Use Internet Banking and Mobile Banking, Case Study: Standart Application in XYZ Company
}

\author{
Iwang Aryadinata $^{1}$ and Febriliyan Samopa ${ }^{1}$
}

\begin{abstract}
Financial Technology (Fintech) is a technology that connects financial sector and user. Fintech is solution for problem that exist in society that is user those who live far from city to be able access transact financially by making non-cash transactions. This non-cash transactions are important component in world economy and also one of the program that Bank Indonesia wants to improve. This study will be analysed what factors that influence customer behavior in acceptance of using Internet Banking and Mobile banking for transactions using the Technology Acceptance Model. In this study, the author takes a case study at standart Internet Banking and Mobile Banking developed by XYZ Company and the scope population of the sample collection is one of the Banks in Bandung that has used the application developed by $X Y Z$ Company. This research uses Partial Least Square Structural Equation Modeling (PLS-SEM) method in analyzing. The results obtained are the most significant factors on customer acceptance use of Internet Banking and Mobile Banking applications for transactions is the subjective norm, experience, result demonstrability, perceived enjoyment, computer playfulness, computer self-efficacy, perception of external control, perceived usefulness, perceived ease of use, behavioral intention, dan use behavior.
\end{abstract}

Keywords-Technology Acceptance Model, Partial Least Square, Structural Equation Modeling, Internet Banking, Mobile Banking.

\section{INTRODUCTION}

Indonesia is a country that has a large and diverse population. Indonesia's geographic with many islands are challenging opportunities to improve. With the increasing number of internet users in Indonesia, government use that to increase public knowledge of financial services through websites and mobile. This has triggered many start-up engaged in financial technology that aim to facilitate the public in conducting non-cash transactions. With products and applications that are based on financial technology, the community no longer needs to be difficult to bring cash in shopping or it can also be called cashless. XYZ company is one of several companies engaged in financial technology. Applications that have been developed by XYZ Company are Internet Banking, Mobile Banking, Business Internet

\footnotetext{
${ }^{1}$ Iwang Aryadinata and Febriliyan Samopa are with Department of Master of Management \& Technology, Institut Teknologi Sepuluh Nopember, Indonesia. Email: iwang14@mhs.mmt.its.ac.id; iyan@is.its.ac.id.
}

Banking, Lakupandai, and many others. One of the Banks that has used the Internet Banking and Mobile Banking application services provided by the XYZ Company is ABC Bank. Until now, Bank ABC customers have used Internet Banking and Mobile Banking application around 10,000 customers from the total number of customers on the ABC Bank about 54,800 customers. This proves that the behavior of customer acceptance use of Internet Banking and Mobile Banking applications is still very diverse. Factors that influence public acceptance of transactions with the application of Internet Banking and Mobile Banking can be controlled by service providers, but there are several other factors that cannot be controlled.

This study aims to analyze the factors can influence user acceptance of using Internet Banking and Mobile Banking applications in transactions. In this study, the author takes a case study on ABC Bank customers who have used.

Internet Banking and Mobile Banking applications developed by XYZ Companies. The final results obtained from this study are to produce a new model from the basic model of Technology Acceptance Model 3 based on the result of calculation using Smart PLS and it can be used for future measurement of acceptance of use in others bank. From the results obtained, recommendations can also be given to $\mathrm{XYZ}$ company in order to improve the factors that are considered low so that customers from Banks can accept application usage properly.

\section{TeChNOlogy AcCePtAnCE Model}

Technology Acceptance Model (TAM), based on the Theory of Reasoned Action, has been widely used for predicting the acceptance and use of information technologies (IT) [1], [2]. TAM is a model developed by Davis to explain the acceptance of technology that will be used by technology users to examine individual behaviors and intentions. This model will produce factors - factors that influence acceptance of a technology in an organization. TAM describes the causal relationship between decisions, behaviors, goals, and actual use of users of a technology [3].

TAM is a theory that describes the perception of technology users. The user's perception will have an influence on the interest in using IT. TAM 3 has 17 variables, such as Experience, Voluntariness, Subjective 
Norm, Image, Job Relevance, Output Quality, Result Demonstrability, Computer Self-Efficacy, Perceptions of External Control, Computer Anxiety, Computer Playfulness, Perceived Enjoyment, Objective Usability, Perceived Usefulness, Perceived Ease of Use, Behavioral
Intention and Use Behavior [1], [4]. Each variable in TAM has a relationship between other variables, it can be explained in Figure 1. Based on Figure 1, 25 hypotheses were obtained in this study. Explanation of each hypothesis from Figure 1.

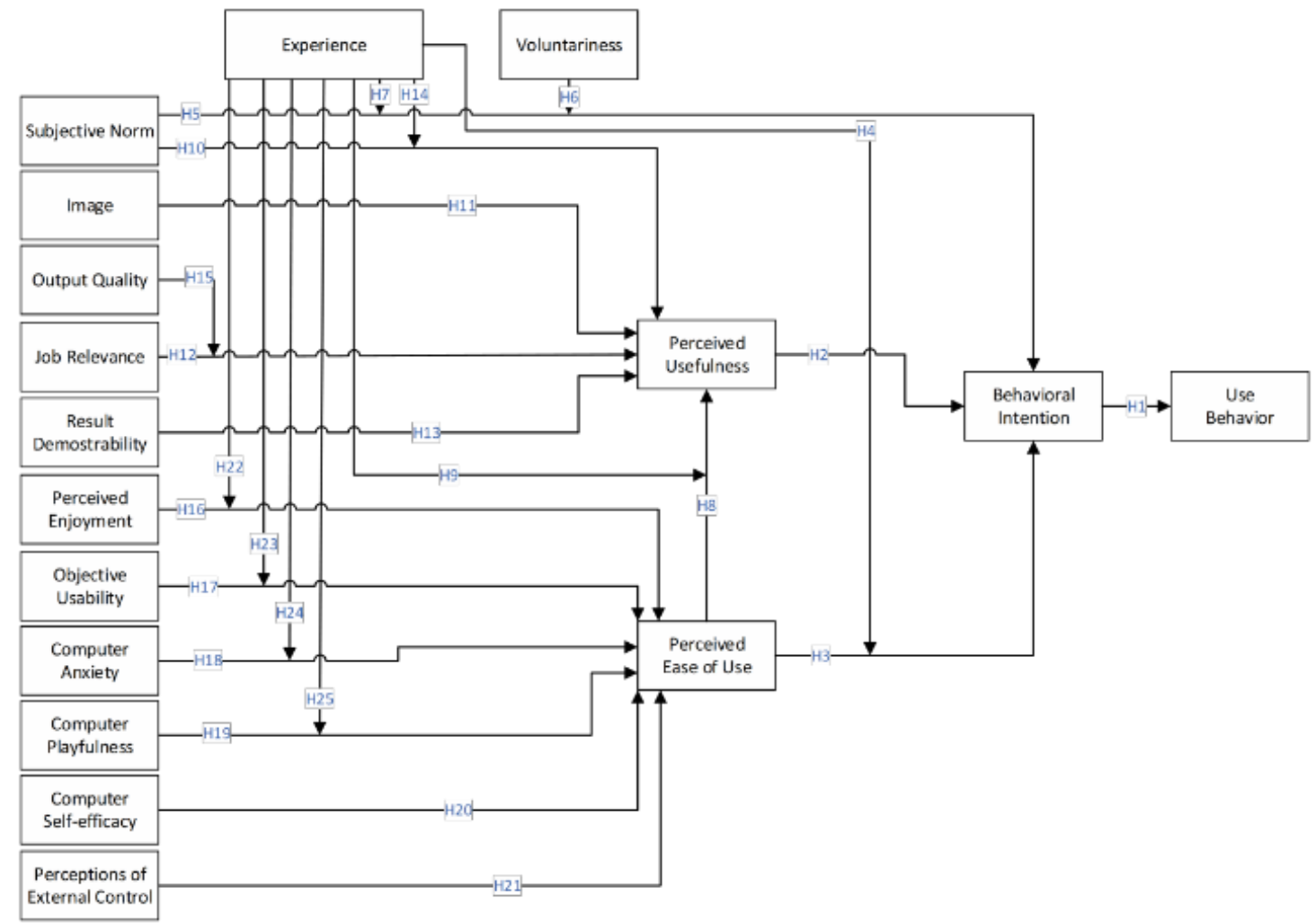

Figure 1. Technology Acceptance Model 3.

$\mathrm{H}_{1}$ : Behavioral Intention has a significant impact on Use Behavior.

$\mathrm{H}_{2}$ : Perceived Usefulness has a significant impact on Behavioral Intention.

$\mathrm{H}_{3}$ : Perceived Ease of Use has a significant impact on Behavioral Intention.

$\mathrm{H}_{4}$ : Perceived Ease of Use has a significant impact on Behavior Intention.

$\mathrm{H}_{5}$ : Perceived Ease of Use has a significant impact on Behavior Intention moderated Experience.

$\mathrm{H}_{6}$ : Subjective Norm has a significant impact on Behavior Intention moderated Voluntariness.

$\mathrm{H}_{7}$ : Subjective Norm has a significant impact on Behavior Intention moderated Experience.

$\mathrm{H}_{8}$ : Perceived Ease of Use has a significant impact on Perceived Usefulness.

$\mathrm{H}_{9}$ : Perceived Ease of Use has a significant impact on Perceived Usefulness moderated Experience.

$\mathrm{H}_{10}$ : Subjective Norm has a significant impact on Perceived Usefulness.
$\mathrm{H}_{11}$ : Image has a significant impact on Perceived Usefulness.

$\mathrm{H}_{12}$ : Job Relevance has a significant impact on Perceived Usefulness.

$\mathrm{H}_{13}$ : Result Demonstrability has a significant impact on Perceived Usefulness.

$\mathrm{H}_{14}$ : Subjective Norm has a significant impact on Perceived Usefulness moderated Experience.

$\mathrm{H}_{15}$ : Job Relevance has a significant impact on Perceived Usefulness moderated Output Quality.

$\mathrm{H}_{16}$ : Perceived Enjoyment has a significant impact on Perceived Ease of Use.

$\mathrm{H}_{17}$ : Objective Usability has a significant impact on Perceived Ease of Use.

$\mathrm{H}_{18}$ : Computer Anxiety has a significant impact on Perceived Ease of Use.

$\mathrm{H}_{19}$ : Computer Playfulness has a significant impact on Perceived Ease of Use.

$\mathrm{H}_{20}$ : Computer Self-Efficacy has a significant impact on Perceived Ease of Use.

$\mathrm{H}_{21}$ : Perceptions of External Control has a significant impact on Perceived Ease of Use. 
The $1^{\text {st }}$ International Conference on Business and Management of Technology (IConBMT)

August 3rd 2019, Institut Teknologi Sepuluh Nopember, Surabaya, Indonesia

$\mathrm{H}_{22}$ : Perceived Enjoyment has a significant impact on Perceived Ease of Use moderated Experience.

$\mathrm{H}_{23}$ : Objective Usability has a significant impact on Perceived Ease of Use moderated Experience.

$\mathrm{H}_{24}$ : Computer Anxiety has a significant impact on Perceived Ease of Use moderated Experience.

$\mathrm{H}_{25}$ : Computer Playfulness has a significant impact on Perceived Ease of Use moderated Experience.

\section{EXECUTION}

This study uses quantitative research as an approach to collect and analyze the data. Primary data was gathered by conducting online questionnaire, the language used for this questionnaire is Bahasa Indonesia. The questionnaire divided into two parts, the first part is screening question, contains question to find out demographic data from respondents such as name, gender, age, monthly income and status. The second part contains 56 indicators that were adapted from previous studies from TAM 3 [5], all of the indicators was to test all variables on research model by using 5-point Likert scale from 1 (strongly disagree) to 5 (strongly agree). This questionnaire made using Google Forms and was distributed by giving direct questions to bank customers using tablets.

In this study the authors used the Slovin formula to determine the number of samples. Slovin formula is a formula to calculate the minimum number of samples if the behavior of a population is not known with certainty. This formula was first introduced by Slovin in 1960. Slovin formula is commonly used in survey research where usually the sample size is very large, so a formula is needed to get a sample that is small but can represent the entire population. Slovin's formula can be seen based on the following notation:

$$
\mathrm{N}=\mathrm{N} / 1+\mathrm{Ne}^{2}
$$

TABLE 1.

LOADING FACTOR RESULT

\begin{tabular}{|c|c|c|c|c|c|}
\hline Indicator & Loading Factor & Indicator & Loading Factor & Indicator & Loading Factor \\
\hline BI1 & 0,899 & EXP $*$ PEOU 1 & 1.038 & $\mathrm{EXP} * \mathrm{ENJ} 1$ & 1.075 \\
\hline $\mathrm{BI} 2$ & 0,928 & EXP $*$ PEOU 2 & 0.926 & $\mathrm{EXP} * \mathrm{ENJ} 2$ & 0.864 \\
\hline $\mathrm{BI} 3$ & 0,873 & EXP $*$ PEOU 3 & 1.055 & $\mathrm{EXP} * \mathrm{ENJ} 3$ & 1.075 \\
\hline CANX1 & 0.891 & EXP $*$ PEOU 4 & 0.937 & PEOU1 & 0,874 \\
\hline CANX2 & 0.839 & IMG1 & 0.84 & PEOU2 & 0,760 \\
\hline CANX3 & 0.807 & IMG2 & 0.78 & PEOU3 & 0,899 \\
\hline CANX4 & 0.828 & IMG3 & 0.862 & PEOU4 & 0,826 \\
\hline CPLAY1 & 0.754 & OU & 1,000 & PU1 & 0.913 \\
\hline CPLAY2 & 0.78 & OUT1 & 0.894 & PU2 & 0.91 \\
\hline CPLAY3 & 0.887 & OUT1 * REL1 & 1.019 & PU3 & 0.925 \\
\hline CPLAY4 & 0.865 & OUT1 * REL2 & 1.037 & PU4 & 0.886 \\
\hline CSE1 & 0,826 & OUT1 $*$ REL3 & 0.971 & REL1 & 0,916 \\
\hline CSE2 & 0,876 & OUT2 & 0.859 & REL2 & 0,926 \\
\hline CSE3 & 0,730 & OUT2 $*$ REL1 & 0.944 & REL3 & 0,924 \\
\hline CSE4 & 0,750 & OUT2 $*$ REL 2 & 0.966 & RES1 & 0,876 \\
\hline ENJ1 & 0,929 & OUT2 $*$ REL3 & 0.874 & RES2 & 0,835 \\
\hline ENJ2 & 0,805 & OUT3 & 0.927 & RES3 & 0,897 \\
\hline ENJ3 & 0,919 & OUT3 $*$ REL1 & 1.038 & RES4 & 0,885 \\
\hline EXP & 1,000 & OUT3 $*$ REL2 & 1.042 & SN1 & 0,771 \\
\hline EXP $*$ CANX1 & 0.939 & OUT3 * REL3 & 0.972 & $\mathrm{SN} 2$ & 0,844 \\
\hline EXP $*$ CANX2 & 0.948 & PEC1 & 0.811 & $\mathrm{SN} 3$ & 0,752 \\
\hline EXP $*$ CANX3 & 0.898 & PEC2 & 0.871 & SN4 & 0,814 \\
\hline EXP $*$ CANX4 & 0.909 & PEC3 & 0.933 & USE & 1,000 \\
\hline EXP $*$ CPLAY1 & 0.894 & PEC4 & 0.76 & VOL1 & 0,818 \\
\hline EXP $*$ CPLAY2 & 0.756 & $\mathrm{EXP} * \mathrm{OU}$ & 1.131 & VOL2 & 0,722 \\
\hline EXP * CPLAY3 & 1.044 & $\mathrm{VOL} * \mathrm{SN}$ & 1,221 & VOL3 & 0,798 \\
\hline EXP $*$ CPLAY 4 & 1.028 & $\mathrm{EXP} * \mathrm{SN}$ & 1,117 & & \\
\hline
\end{tabular}


From the Equation 1, $\mathrm{n}$ is the minimum number of samples, $\mathrm{N}$ value is the population while the value of $\mathrm{e}$ is the margin error and in this study the maximum error rate was $5 \%(0.05)$. And then by using Slovin's formula, the minimum number of samples needed is 385 samples.

After the sample is collected, the authors uses the SmartPLS version 3.2.6 application to estimate the Structural Equation Model (SEM) and using Partial Least Squares (PLS) method. Evaluation of the outer model is done to assess the validity and reliability of the model using PLS Algortihm. The indicators are valid to represent the variabel if the Factor Loading value is equal or greater than $0.7(70 \%)$, the variables are valid if the Average Variance Extracted (AVE) is equal or greater than 0.5 $(50 \%)$, and the variables are reliable if the Cronbach Alpha is equal or greater than $0.6(60 \%)$. Afterwards, the valid and reliable data were analyzed using Bootstrapping method that include $\mathrm{R}$-square $\left(\mathrm{R}^{2}\right)$ value and path coefficients.

\section{RESULT AND DISCUSSION}

Based on measurement Structural Equation Model and using Partial Least Squares (PLS) method, it was obtained Factor Loading values as in Table 1, AVE values as in Table 2, Cronbach Alpha values as in Table 3, $\mathrm{R}^{2}$ values as in Table 4, and path coefficients as in Table 5. Loading factor values shows how the correlation between indicators with latent variables. And in Table 1, it can be seen that all variables are greater than 0.7 . Thus variables is declared valid because it meets the criteria of loading factor. AVE shows the average percentage of variance extracted from a set of variables that are estimated from loading stardardized indicator in the iteration algorithm process in the PLS. And in Table 2, it can be seen that all variables meet the AVE value criteria (greater than 0.5). So, all the variables are declared valid. Cronbach's alpha is a value that measure the internal consistency of a variable. in Table, it can be seen that all variables meet the Cronbach Alpha's value criteria (greater than 0.7). So, all the variables are declared reliable.

TABLE 2.

AVERAGE VARIANCE EXTRACTED (AVE) RESUlt

\begin{tabular}{|c|c|c|c|c|c|}
\hline Indicator & AVE & Indicator & AVE & Indicator & AVE \\
\hline CANX & 0,709 & OU*EXP & 1,000 & IMG & 0,685 \\
\hline CANX*EXP & 1,000 & PEC & 0,717 & OUT & 0,799 \\
\hline CPLAY & 0,678 & PEOU & 0,707 & BI & 0,811 \\
\hline CPLAY*EXP & 1,000 & PEOU*EXP & 1,000 & SN & 0,639 \\
\hline CSE & 0,636 & PU & 0,826 & SN*EXP & 1,000 \\
\hline ENJ & 0,785 & REL & 0,850 & $\mathrm{SN}^{*} \mathrm{VOL}$ & 1,000 \\
\hline ENJ*EXP & 1,000 & REL*OUT & 1,000 & USE & 1,000 \\
\hline EXP & 1,000 & RES & 0,763 & VOL & 0,609 \\
\hline OU & 1,000 & & & & \\
\hline
\end{tabular}

TABLE 3.

CRONBACH AlPha RESUlt

\begin{tabular}{|c|c|c|c|c|c|}
\hline Indicator & Cronbach Alpha & Indicator & Cronbach Alpha & Indicator & Cronbach Alpha \\
\hline CANX & 0,877 & OU*EXP & 1,000 & IMG & 0,788 \\
\hline CANX*EXP & 1,000 & PEC & 0,866 & OUT & 0,874 \\
\hline CPLAY & 0,840 & PEOU & 0,861 & $\mathrm{BI}$ & 0,883 \\
\hline CPLAY*EXP & 1,000 & PEOU*EXP & 1,000 & $\mathrm{SN}$ & 0,815 \\
\hline CSE & 0,822 & $\mathrm{PU}$ & 0,930 & $\mathrm{SN}^{*} \mathrm{EXP}$ & 1,000 \\
\hline ENJ & 0,862 & REL & 0,912 & $\mathrm{SN} * \mathrm{VOL}$ & 1,000 \\
\hline ENJ*EXP & 1,000 & REL*OUT & 1,000 & USE & 1,000 \\
\hline EXP & 1,000 & RES & 0,897 & VOL & 0,710 \\
\hline $\mathrm{OU}$ & 1,000 & & & & \\
\hline
\end{tabular}

TABLE 4.

R-SQUARE RESULT

\begin{tabular}{|c|c|c|c|c|c|}
\hline Indicator & R-Square & Indicator & R-Square & Indicator & R-Square \\
\hline Perceived Usefulness & 0.627 & Behavioral Intention & 0.634 & Use Behaviour & 0.234 \\
\hline Perceived Ease of Use & 0.654 & & & & \\
\hline
\end{tabular}


Table 4 shows the value of $\mathrm{R}^{2}$ in the 4 dependent variables tested in this study. Perceived Usefulness, Perceived Ease of Use, Behavioral Intention shows moderate $\mathrm{R}^{2}$ value. And then for Use Behavior shows a low $\mathrm{R}^{2}$ value. This can be interpreted that variable Use Behavior is only able to be explained by Behavioral Intention of $23.4 \%$ while the remaining $76.4 \%$ is a contribution from other variables not discussed in this study.

Reffering to Table 5, the result of hypotheses testing shows that H1, H2, H3, H8, H10, H13, H16, H19, H20,

$\mathrm{H} 21, \mathrm{H} 24$ and $\mathrm{H} 25$ were accepted. And because the purpose of this study is to identify factors that significantly influence customer acceptance in using Internet Banking and Mobile Banking for transaction, the variable of accepted hypothesis must be seen whether has effect on Use Behavior or not. The way to find out which variable has a path to Use Behavior variable is connect all accepted hypotheses. Table 6 shows that 11 of the 12 hypothesis that were accepted, had a significant effect on Use Behavior and 1 of the 12 hypotheses were accepted had no effect on Use Behavior. 1 hypotheses that have no significant effect on Use Behavior will be subtracted from final model. After being subtracted by variables that have no effect on Use Behavior, the final model of the research produced in this is study shown on Figure 2.

From 25 hypotheses tested, 12 hypotheses were accepted and 13 hypotheses were rejected. And from 12 hypotheses were accepted, there is 1 hypotheses that do not affect to Use Behavior. So that the remaining 11 hypotheses are accepted and affect Use Behavior, this shows that not all the factors proposed in this study have an effect on customer acceptance in transactions using Internet Banking and Mobile Banking developed by XYZ Company. The following will explain the effect of the independent variables on the dependent variable produced in this study:

TABLE 5 .

PATH COEFFicient Result

\begin{tabular}{|c|c|c|c|c|c|c|}
\hline & & Original Sample (O) & T Table & T Statistics & P Values & \\
\hline H1 & Behavioural Intention -> Use Behavior & 0,483 & 1.96 & 11,601 & 0,000 & Accepted \\
\hline $\mathrm{H} 2$ & Perceived Usefulness -> Behavioral Intention & 0,302 & 1.96 & 5,784 & 0,000 & Accepted \\
\hline H3 & Perceived Ease of Use -> Behavioral Intention & 0,283 & 1.96 & 4,884 & 0,000 & Accepted \\
\hline $\mathrm{H} 4$ & Perceived Ease of Use * Experience $->$ Behavioral Intention & 0,026 & 1.96 & 0,558 & 0,577 & Rejected \\
\hline H5 & Subjective Norm -> Behavioral Intention & 0,046 & 1.96 & 1,057 & 0,291 & Rejected \\
\hline H6 & Subjective Norm * Voluntariness $->$ Behavioral Intention & $-0,070$ & 1.96 & 1,763 & 0,078 & Rejected \\
\hline $\mathrm{H} 7$ & Subjective Norm * Experience -> Behavioral Intention & $-0,015$ & 1.96 & 0,257 & 0,797 & Rejected \\
\hline H8 & Perceived Ease of Use -> Perceived Usefulness & 0,184 & 1.96 & 2,896 & 0,004 & Accepted \\
\hline H9 & Perceived Ease of Use $*$ Experience $->$ Perceived Usefulness & 0.005 & 1.96 & 0,086 & 0,931 & Rejected \\
\hline H10 & Subjective Norm -> Perceived Usefulness & 0,145 & 1.96 & 2,797 & 0,005 & Accepted \\
\hline H11 & Image -> Perceived Usefulness & $-0,029$ & 1.96 & 0,698 & 0,485 & Rejected \\
\hline H12 & Job Relevance -> Perceived Usefulness & 0,040 & 1.96 & 0,697 & 0,486 & Rejected \\
\hline H13 & Result Demonstrability -> Perceived Usefulness & 0,350 & 1.96 & 5,776 & 0,000 & Accepted \\
\hline H14 & Subjective Norm * Experience -> Perceived Usefulness & $-0,078$ & 1.96 & 1,716 & 0,087 & Rejected \\
\hline H15 & Job Relevance * Output Quality -> Perceived Usefulness & $-0,074$ & 1.96 & 1,451 & 0,147 & Rejected \\
\hline H16 & Perceived Enjoyment -> Perceived Ease of Use & 0,269 & 1.96 & 5,358 & 0,000 & Accepted \\
\hline H17 & Objective Usability -> Perceived Ease of Use & 0,007 & 1.96 & 0,174 & 0,862 & Rejected \\
\hline H18 & Computer Anxiety -> Perceived Ease of Use & $-0,001$ & 1.96 & 0,033 & 0,973 & Rejected \\
\hline H19 & Computer Playfulness -> Perceived Ease of Use & 0,171 & 1.96 & 3,693 & 0,000 & Accepted \\
\hline $\mathrm{H} 20$ & Computer Self-efficacy -> Perceived Ease of Use & 0,376 & 1.96 & 6,746 & 0,000 & Accepted \\
\hline $\mathrm{H} 21$ & Perceptions of External Control -> Perceived Ease of Use & 0,126 & 1.96 & 2,372 & 0,018 & Accepted \\
\hline $\mathrm{H} 22$ & Perceived Enjoyment $*$ Experience $->$ Perceived Ease of Use & 0,100 & 1.96 & 1,781 & 0,075 & Rejected \\
\hline $\mathrm{H} 23$ & Objective Usability * Experience -> Perceived Ease of Use & $-0,006$ & 1.96 & 0,124 & 0,901 & Rejected \\
\hline $\mathrm{H} 24$ & Computer Anxiety * Experience -> Perceived Ease of Use & $-0,146$ & 1.96 & 3,388 & 0,001 & Accepted \\
\hline $\mathrm{H} 25$ & Computer Playfulness * Experience $->$ Perceived Ease of Use & $-0,098$ & 1.96 & 2,401 & 0,017 & Accepted \\
\hline
\end{tabular}


TABLE 6.

LIST OF HYPOTHESES THAT INFLUENCE USE BEHAVIOR

\begin{tabular}{clcc}
\hline \hline $\begin{array}{c}\text { Accepted } \\
\text { Hypotheses }\end{array}$ & Behavioural Intention -> Use Behavior & $\begin{array}{c}\text { Path to use behavior } \\
\text { variable }\end{array}$ & $\begin{array}{c}\text { Has effect to use } \\
\text { behavior? }\end{array}$ \\
\hline H1 & Perceived Usefulness -> Behavioral Intention & Yes \\
H2 & Perceived Ease of Use -> Behavioral Intention & Yes \\
H3 & Perceived Ease of Use -> Perceived Usefulness & $(\mathrm{H} 1)$ & Yes \\
H8 & Subjective Norm -> Perceived Usefulness & $(\mathrm{H} 2, \mathrm{H} 1)$ & Yes \\
H10 & Result Demonstrability -> Perceived Usefulness & Yes \\
H13 & Perceived Enjoyment -> Perceived Ease of Use & Yes \\
H16 & Computer Playfulness -> Perceived Ease of Use & Yes \\
H19 & Computer Self-efficacy -> Perceived Ease of Use & $(\mathrm{H} 3, \mathrm{H} 1)$ & Yes \\
H20 & Perceptions of External Control -> Perceived Ease of Use & $(\mathrm{H} 3, \mathrm{H} 1)$ & Yes \\
H21 & Computer Anxiety * Experience -> Perceived Ease of Use & $(\mathrm{H} 18, \mathrm{H} 3, \mathrm{H} 1)$ & Yes \\
H24 & Computer Playfulness * Experience -> Perceived Ease of Use & $(\mathrm{H} 19, \mathrm{H} 3, \mathrm{H} 1)$ & No \\
H25 & & Yes \\
\hline \hline
\end{tabular}

A. Subjective Norm, Result Demostrability, Image, Experience, Job Relevance, Output Quality, and Perceived Ease of Use on Perceived Usefulness

The results of the analysis show that subjective norms, result demostrability, perceived ease of use) have a significant effect on perceived usefulness. Customers are more trustworthy to receive Mobile Banking and Internet Banking in transactions if someone nearby or the around social environment has also used the same application. The services provided are also very much.

This is a strong force for customers to acceptance Internet Banking and Mobile Banking Applications for transactions. For image, job relevance, and output quality, there is no significant effect on perceived usefulness. So that it can be concluded that the customer does not attach importance to social views, benefits in work and quality results provide when using Internet Banking and Mobile Banking applications.

B. Perceived Enjoyment, Computer Playfullness, Computer Self-efficacy, Perceptions of External Control, Objective Usability and Computer Anxiety on Perceived Ease of Use

The results of the analysis show that in variables objective usability and computer anxiety in acceptance of using the Interet Banking and Mobile Banking applications for transaction, most respondents choose neutral answers so it can can be concluded that these variables have no significant effect on the perceived ease of use. And for computer self-efficacy, perceptions of external control, computer playfulness, and perceived enjoyment, most respondents choose to agree to the acceptance of using the Internet Banking and Mobile Banking applications. Trust in a person's ability to use the application and trust in the infrastructure that has been provided can support services that can be used by the customer is important so that customers feel easy in making transactions. This shows that these factors significantly influence the acceptance of using Internet Banking and Mobile Banking applications.

\section{Subjective Norm, Perceived Usefulness, and Perceived Ease of Use on Perceived Behavioral Intention}

From three main factors that influence behavioral intention, two of them are perceived usefulness and perceived ease of use that have a significant effect on the acceptance of using Internet Banking and Mobile Banking in transactions. The customer perceives himself that using Internet Banking and Mobile Banking for transactions is beneficial behavior and also the customer perceives himself using Internet Banking and Mobile Banking for transactions are an easy matter. Another factor, subjective norm is declared have not affect to behavior intention in the acceptance of using Internet Banking and Mobile Banking to transact in this study. This happens because someone's plan to transact using Internet Banking and Mobile Banking is not caused by the influence of other people but because of the awareness of oneself that transacting using Internet Banking and Mobile Banking needs to be done because it is easier and has many benefits.

\section{Behavioral Intention on Use Behavior}

The results of the analysis show that behavioral intention has a significant effect on use behavior in the acceptance of using the Internet Banking and Mobile Banking applications, but the r-square value is low (0.234) indicating that there are other factors that can influence the acceptance of using Internet Banking and Mobile Banking. 
The $1^{\text {st }}$ International Conference on Business and Management of Technology (IConBMT)

August 3rd 2019, Institut Teknologi Sepuluh Nopember, Surabaya, Indonesia

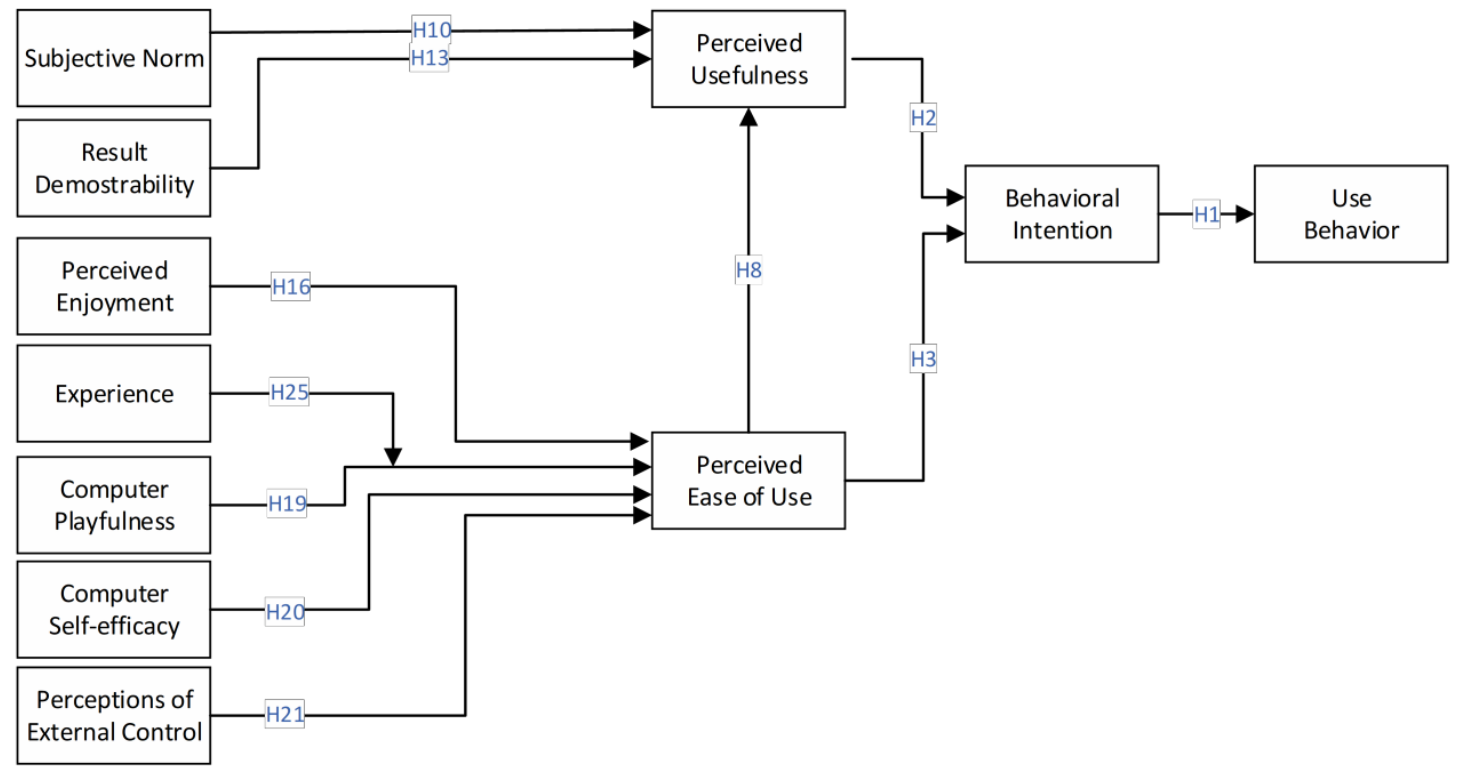

Figure 2. Final Version of Research Model.

\section{CONCLUSION}

According to TAM, "ease of use" has two effects, direct effects and indirect effects on consumer behavioral intention in the acceptance of a technology. Indirect effects on consumer intentions are through use (Perceived Usefulness) and direct effects on consumer intentions explained by the fact that in decision-making behavior as well as consumer perceived of ease of use. And based on research results that influence acceptance of perceived usefulness in the case study of Internet Banking and Mobile Banking developed by the XYZ Company is subjective norms and result demonstrability. And for perceived ease of use is perceived enjoyment, computer playfulness, computer self-efficacy, and experience. Based on 6 variables which are stated to have a direct and indirect effect on customer acceptance in using of Internet Banking and Mobile Banking, 5 of them have a very low P-Value on the Path Coefficient $(<0.01)$ that needs to be improved, they are subjective norm, result demonstrability, perceived enjoyment, computer playfulness, and computer selfefficacy. Here are some recommendations from authors for the XYZ Company.

To improve Subjective Norms can be done by increasing public awareness or customers of products or services that are available on Internet Banking and Mobile Banking to obtain a higher adoption rate. This can be done by XYZ Company and the related Banks working together to hold seminars or training in introducing or evaluating their products [6].

In the seminars and training provided by $\mathrm{XYZ}$ Company, the community and customers can try hands-on directly to transact using Internet Banking and Mobile Banking.
This is because with customers trying hands-on directly can improve Computer Self-efficacy more significantly than training by using videos that display the use of related applications [1]. Training or seminars conducted regularly can improve Perceived Enjoyment. Because indicators that can improve the Perceived Enjoyment are the length of time that customers or the community spend in using related applications. And if community or customers trying directly on a hands-on and periodic basis, they can measure the results that will be obtained when using Internet Banking and Mobile Banking applications. With the knowledge and experience of the results obtained, the Result Demonstrability variable can also increase [7].

To improve Computer Playfulness, it can be done by XYZ Company improving the search and responsiveness facilities available in Internet Banking and Mobile Banking applications. With enhanced search facilities, customers can easily find the desired information. This is because customers are more likely to choose applications that are easy to read, and easy to navigate. In addition, the responsibility of an application can also be improved through increasing responsiveness when opening time and search time on applications [8].

\section{REFERENCES}

[1] V. Venkatesh and F. D. Davis, "A model of the antecedents of perceived ease of use: Development and test," Decis. Sci., vol. 27, no. 3, pp. 451-481, 1996.

[2] F. D. Davis, "Perceived usefulness, perceived ease of use, and user acceptance of information technology," MIS Q. Manag. Inf. Syst., vol. 13, no. 3, pp. 319-339, 1989.

[3] F. D. Davis, R. P. Bagozzi, and P. R. Warshaw, "User acceptance of computer technology: A comparison of two theoritical models," Manage. Sci., vol. 35, no. 8, pp. 982-1003, 1989. 
The $1^{\text {st }}$ International Conference on Business and Management of Technology (IConBMT)

August 3rd 2019, Institut Teknologi Sepuluh Nopember, Surabaya, Indonesia

[4]

D. A. Jeffrey, "Testing the Technology Acceptance Model 3 with the Inclusion of Change Fatigue and Overload, in the Context of Faculty from Seventhday Adventist Universities : A Revised Model," Andrews University, 2015.

[5] V. Venkatesh and H. Bala, "Technology acceptance model 3 and a research agenda on interventions," Decis. Sci., vol. 39, no. 2, pp. 273-315, 2008.

[6] S. O. Abeka, "Perceived usefulness ease of use organizational and bank support as determinants of adoption of internet banking in East Africa," Int. J. Acad. Res. Bus. Soc. Sci., vol. 2, no. 10, pp. 97-112, 2012.
[7] V. Venkatesh, "Determinants of perceived ease of use: Integrating control, intrinsic motivation, and emotion into the technology acceptance model," Inf. Syst. Res., vol. 11, no. 4, pp. 342-365, 2000.

[8] G. Liu, Y. F. Song, and C. Qian, "User acceptance of internet banking: An empirical study in China," in 2008 International Conference on Wireless Communications, Networking and Mobile Computing, WiCOM 2008, 2008. 